\title{
LOCAL FINANCIAL DEVELOPMENT AND FIRM PERFORMANCE: DOES FINANCIAL OUTREACH REALLY MATTERS WITHIN INDONESIAN ARCHIPELAGO?
}

\author{
Fickry Widya Nugraha'
}

\begin{abstract}
This study attempt to examine whether firm's performance depends on the local financial development across Indonesian provinces within 2010-2013. Combining data from the Indonesian survey of manufacturing firms with information from regional-level data, the study empirically documented several key findings. First, there are no consistent results that local bank availability is robustly associated with faster growth for firms in sectors with growth opportunities. Second, this paper documented a positive interplay between access to financial services to firm performance particularly within western part region of Indonesia. Third, access to the financial service appears to be closely connected with the level of economic development, particularly rate of poverty and inflation in the western part region of Indonesia. Taken these empirical finding together, this study imply that the level of inequality across Indonesian archipelago need to be reduced in order not only to provide a better access of financial services to the local stakeholders but also to improve small firms performance.
\end{abstract}

Keywords : Firm performance, local financial development, financial access

JEL Classification : 016, L20

1 The author is analyst in Department of Strategic and Management Bank Indonesia. The views and opinions expressed in this paper do not necessarily reflect those of Bank Indonesia. Email address : fickry_wn@bi.go.id 


\section{INTRODUCTION}

A report published by the United Nations Industrial Development Organization recently documented that Indonesian economy has move toward industrialized nations. Figure 1 reports the trend of manufacturing industries share to GDP. Based on this figure, the Indonesian manufacturing industries has made a significant improvement provided the fact that share of manufacturing industries to GDP in 2015 has slightly increase to around $4 \%$. This condition also made Indonesia manufacturing industries on par with several advance industrial countries such as United Kingdom, Russian Federation, Canada and Spain. The key contributions of sectors matters for economic growth and structural change since the technological opportunities between them vary significantly. ${ }^{2}$

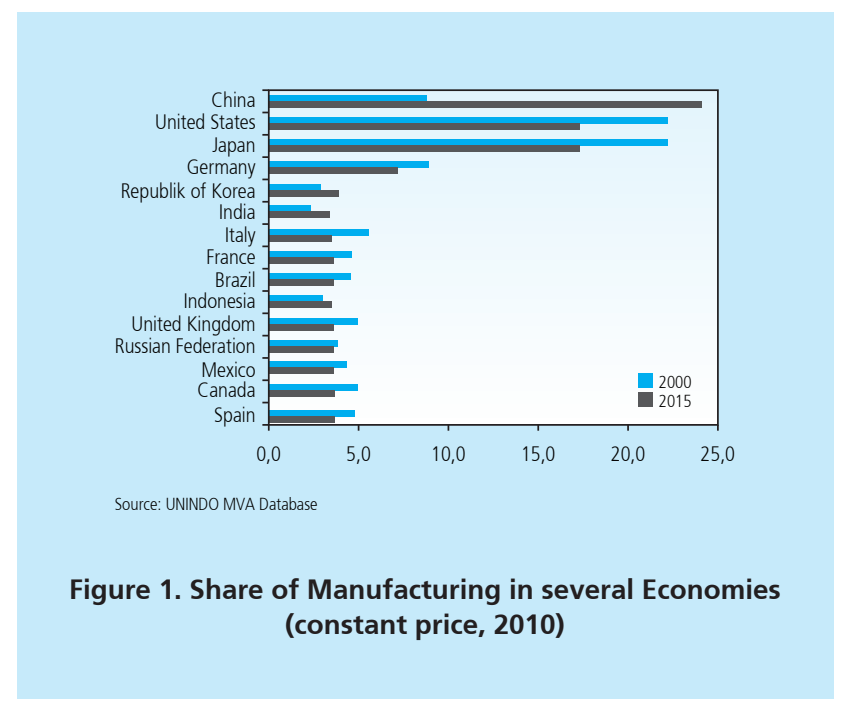

Meanwhile, on the other hand, the center point of Indonesia's grand strategy toward inclusive and sustainable development path has been to increase the financial access service in manufacturing industry. ${ }^{3}$ This strategy cannot be separated from the global agenda and Lima Declaration, aiming for resilient infrastructure, promote inclusive and sustainable industrialization, and foster innovation within nations. ${ }^{4}$ This strategy is also designed rigorously in respond to

2 Industrial Development Report 2016 (see reference).

3 This can be seen from the long-term directions of Indonesian Financial Services Sector Master Plan 2015-2019 which is to build an inclusive access of financial services to foster economic development

4 In 2013, the Lima Declaration goal is correspond to the Sustainable Development Goal 9 (SDG 9) that aims to eradicate poverty through inclusive and sustainable industrial development. Inclusive and sustainable industrial development means that every country achieves a higher level of industrialization in their economies and benefits from the globalization of markets for industrial goods and services. 
the Indonesia's business activity which is still portrayed by structural problem about bankability issues in particular within small Indonesia manufacturing firm.

A previous study of Rosengard and Prasetyantoko (2012) pointed out that Indonesia is unbanked, especially for the micro, small, and medium enterprises (MSME). The study also stated that despite potentially lucrative unserved or under-served markets including the lowincome households and family business, the monetary policy and the regulatory regime in Indonesia set by the central bank has created barriers to the financial outreach and innovation for microfinance institutions, unintentionally.

Back in the 70's, it is widely recognized from literature that financial development is linked to economic growth. Goldsmith (1969) provided the first cross-country empirical study documenting the existence of a strong positive link between the functioning of the financial system and growth. A number of studies then followed, King and Levine (1993) showed that a country's financial development matters for firm performance and aggregate growth. Afterwards, in countries with better functioning financial system, Rajan and Zingales (1998) showed that industries that depend mostly on external finance grew faster than industries that are not using external finance.

In one hand, Levine $(1997,2005)$ shows through econometric studies that when banks manage to channeling capital to firms with the highest social returns and able to monitor the allocation of funds, this will encouraging entrepreneurship and economic growth. Furthermore, Levine $(1997,2005)$ also states that well-functioning banks will have positive effect to income distribution and poverty. Countries with better banks experience faster reductions in poverty as capital flows to those with the best projects, not simply to those with the most wealth and power, the reverse uphold for poor functioning banks. Generally, an important channel is linked to the access to financial services which represents by the availability of financial infrastructure that is more or less directly transmits the role of the financial sector to economic growth. In this sense, the better financial infrastructure should then help to foster economic development through many ways.

This study will put Indonesia as a case since it represents an interesting aspect from the socioeconomics standpoint. First, Indonesia is the fourth most populous country where $67 \%$ of population is classified as the working ages ${ }^{5}$. Second, Indonesia is emerging countries in south-east asia where its GDP in 2013 account for $\$ 878,04$ billion or the biggest in ASEAN economies ${ }^{6}$. Third, a report by the World Bank show an evidence that only $19.6 \%$ of Indonesia's adult population that has access in a formal financial sector. ${ }^{7}$

5 Working ages define as people who have 15-64 ages

6 Association of South East Asian Nations (ASEAN) economic report 2011

7 The global Findex Database 2014 (see reference) 
By using the similar approach with Fafchamps and Schündeln (2013), this study will attempt to examine the impact of local financial outreach on firm performance in Indonesia. The outcome of this empirical research is expected to provide an important insight on the literature of financial inclusion in the context of emerging countries, specifically in Indonesia. Furthermore, the research is quite different in term of the research specification due to the fact that many of the previous studies had generally focused on the link between financial deepening and economic growth (Soedarmono, et al (2015), Trinugroho et al (2015), Subandono (2015), Jayaratne and Strahan (1996)).

In order to bridge this gap, this study introduces two novelty fundamental aspects in comparison to the previous study. Firstly, this study emphasizes the interplay of access to the local financial development on firm performance across Indonesian archipelago. With 17,000 islands, the inequality issues between the Western and the Eastern part of Indonesia remains. In this case, taking into consideration the spatial aspect hopefully will provide a clear insight regarding the impact of financial access in these regions. Secondly, this paper merge the use of firm-level dataset from Indonesian manufacturing survey with regional-level dataset; we may expect better evidence in compare to the use of aggregated dataset only.

The main empirical findings from this paper are as follows. First, there are no consistent result that local bank availability is robustly associated with faster growth for small firms, in particular for small firms in sectors with growth opportunities and in geographically concentrated region. Second, the paper found a positive interplay between local bank availability and firm performance. Third, level of development such as poverty rate, inflation rate and minimum wage are come hand in hand with the success of financial outreach to uphold firms performance within Indonesia's province over the sample period.

The remaining of the paper is organized as follows. Section 2 presents literature review on the theoretical ground between financial infrastructure and economic growth. Section 3 will briefly describes the data and methodology approach. Section 4 will briefly provide descriptive statistics on the dataset. Section 5 reports the main empirical results from this study. Finally, Section 6 presents a concluding remarks in regard to the overall findings and major implications that can be drawn from this study.

\section{THEORY}

\subsection{Behavior of the Household and the Bank}

A theoretical approach related to this issue was proposed by Amable and Chatelain (2001). Let a fixed-size population of overlapping generations of agents live for two periods. There is a continuum of mass $N=1$ of these agents and they are uniformly distributed on a circle of circumference equal to unity. This formalizes horizontal differentiation and or spatial heterogeneity. During the first period, each agent inelastically supplies one unit of labor, saves 
a certain proportion of her earnings, and does not provide bequests to their offspring. The agents can invest their savings either in a storage technology, or put them as deposits in banks. More specifically, the model assume that the utility function of an agent living in $t$ and $t+1$ is log-linear and depends on the levels of consumption at the end of each of the two periods:

$$
U=\log \left[C_{t}\right]+\frac{1}{1+\rho} \log \left[C_{t+1}\right]
$$

Where $\rho$ is the rate of time preference. The first period's consumption is equal to the difference between wage income and savings, while second period's consumption is equal to the revenues derived from savings, thus:

$$
U=\log \left[w_{t}-S_{t}\right]+\frac{1}{1+\rho} \log \left[z_{t+1} S_{t}\right]
$$

Where $w_{t}$ is the real wage, $S_{t}$ is individual's current amount of saving and $Z_{t+1}$ is the real return on savings on any assets (deposit or storage technology). From this specification, saving function is assumed to be inelastic to the real return :

$$
S_{t}=\frac{w_{t}}{2+\rho}
$$

There is imperfect competition in the banking sector because of horizontal (spatial) differentiation as in Salop's (1979) model. In respond to this, the model considered where spatial competition takes place on a circle whose circumference is normalized to unity over which banks are equally distributed. The lender then deposits their money to the bank $i$ only if the return (net) of the transactions cost of going to the bank is relatively higher than the return from storage technology $\mu$. In this context, this analogy can be mathematically written as follow:

$$
r_{i, t}^{d}-d l \geq \mu
$$

$r_{i, t}{ }^{d}$ is the deposit rate of bank $i$ at date $t$, I is the distance between a consumer's location and bank $i$ 's location, and $d l$ is the lender transportation cost per unit of saving. The transportation cost $d l$ is assumed to be a decreasing function of the services provided by financial infrastructure (G), which full depreciate after one period, as assumed for private capital. For homogeneity and simplicity, $G$ is divided by $Y$ in the specification of $d$, so that the distance factor is $d(G / Y)$. The farther the consumer is from the bank located at $l=0$, the more costly it is for them to deposit their assets in that bank. 


\subsection{Financial Infrastructure and Economic Growth}

In this framework, Amable and Chatelain (2001) consider that banks face spatial competition on the deposit market as in Salop's (1979) model, but depositors' transaction costs and banks' intermediation costs are endogenous and depend on financial infrastructures. An increase in the number of banks will positively affect the level of aggregate savings. Public intervention will determine the amount of financial infrastructures in the economy and thus indirectly influence the extent of imperfect competition in the banking sector, which will in turn affect economic growth $\left(g_{t}\right)^{8}$.

$$
\begin{aligned}
g_{t}=\frac{K_{t+1}}{K_{t}} & =n^{*}\left(2 l^{*}\right) \frac{w_{t}}{(2+\rho) K_{t}} \\
& =\frac{2(1-\propto)^{2}}{\propto(2+\rho)} \frac{\left(r^{c}\right)^{2}}{2 f\left(\tau_{3}\right)+\mu-\left(r^{c}\right)^{2}} \frac{r^{c}-\left[f\left(\tau_{3}\right)+\mu\right]}{d\left(\tau_{2}\right)} \\
& =g\left(r^{c}, \rho, d, f, \mu\right)
\end{aligned}
$$

One can see the influence of the financial intermediation sector on growth through the number of banks $\left(n^{*}\right)$ and the market share of a bank measured by the distance $\left(21^{*}\right)$ which increases collected savings. The growth rate is constant over time, as is customary in AK-type endogenous growth models and depends positively on the saving rate (through the rate of time preference $\rho$ ) and on the productivity of capital, diminished by the marginal rate of unproductive taxation. In this particular case, imperfect competition in the banking sector adds the two negative effects on growth of operating costs of banks $\left(f\left(\tau_{3}\right)\right)$ and the return of the alternative assets for depositors $(\mu)$. The positive effects of infrastructures on growth can appear clearly through the effect on $d$, as a decrease in the transaction cost incurred by the depositor $d$ is beneficial to growth. Likewise, if infrastructure increase the level of private productivity $(A)$ or decrease operating costs of banks $\left(f\left(\tau_{3}\right)\right)$, it also beneficial to growth.

\subsection{Access to Financial Services}

A study by Claessens (2006) showed that access to financial services has been recognized as an important aspect of development, and more emphasis is being given to extending financial services to low-income households. Access to finance is not the same as use of financial services. Access refers to the availability of a supply of reasonable quality financial services at reasonable costs, where reasonable quality and reasonable cost have to be defined relative to some objective standard, with costs reflecting all pecuniary and no pecuniary costs. On the other hand, the 
use of financial services refers to the actual consumption of financial services. The difference between access and use can be analyzed in a standard demand and supply framework. Access refers to supply, whereas use is the intersection of the supply and demand schedules.

Well-developed financial institutions will be crucial to an efficient allocation of resources in response to growth opportunities (Fisman and Love, 2007). A recent empirical study by Fafchamps and Schündeln (2013) in Morocco showed that local bank availability is robustly associated with faster growth for small-medium size firms in sectors with growth opportunitites. Paralleling these empirical findings suggest that development pathway need a better access of financial services to the local stakeholders (which can be either households or firms) in order to improve economic performance particularly in developing countries which has a significant amount of population.

There are numerous potential channels, and recent research shows that finance is associated with all of them. According to the World Bank (2008), the availability of external finance is positively associated with the number of start-ups an important indicator of entrepreneurship as well as with firm dynamism and innovation. Finance is also needed if existing firms are to be able to exploit growth and investment opportunities and to achieve a larger equilibrium size. Firms can safely acquire a more efficient productive asset portfolio where the infrastructures of finance are in place, and they are also able to choose more efficient organizational forms such as incorporation.

\subsection{Empirical Model}

Having explaining the theoretical ground, now we need to translate them into empirical model. Ideally, the model to estimate relates and is derived directly from the theoretical one; however this paper uses the ad-hoc model. This section will explain the construction of the empirical model, while its estimation and possible bias (e.g. endogeneity, reverse causation and selection bias) will be discussed on methodology.

To assess the effect of local financial development on firm performance, we construct the structural model of interest as follows:

$$
\Delta y_{f i s t}=\beta B_{i t} G_{s}+\delta B_{i t}+\gamma G_{s}+\text { Control }_{i t}+\mu_{i}+\omega_{s}+\theta_{t}+\varepsilon_{f i s t}
$$

where $\Delta y_{\text {fist }}$ is the outcome of performance for firm $f$ in province $i$ on sector $s$ at period $t ; B_{i t}$ is the total number of bank branch in location $i$ at time $t, G_{s}$ is growth opportunities at sector $s$ available to firm $f$; Control ${ }_{i t}$ is control variables for level of economic development in province $i$ at time period $t ; \mu_{i}$ is a region fixed-effect capturing the impact of unobservable time-invariant province characteristics, $\omega_{s}$ and $\theta_{t}$ are dummies control for different growth rates across sectors and time, and $\varepsilon_{\text {fist }}$ is error term. Firms that were used as reference group to calculate $G_{s}$ are excluded from regression (6). 
The main parameter of interest is $\beta$ which we can interpret a positive coefficient as evidence for a positive effect of local financial development on firm performance after controlling for unobserved time-invariant and time-varying local heterogeneity. One approach to estimating $\beta$ is to rule out $\mu_{i}, \omega_{s}$ and $\theta_{t}$ through a within-firm transformation to get

$$
\Delta \tilde{y}_{f i s t}=\beta \widetilde{B}_{i t} * \widetilde{G}_{s}+\delta \widetilde{B_{l t}}+\gamma \widetilde{G_{s}}+\widetilde{\text { control }}_{i t}+\tilde{\mu}_{i}+\widetilde{\omega}_{s}+\theta_{t}+\tilde{\varepsilon}_{i s t}
$$

where $\tilde{y}_{\text {fist }}=y_{\text {fist }}-\bar{y}_{i}$ with $\bar{y}_{i}=\frac{1}{T_{i}} \sum_{t=1}^{T_{i}} y_{\text {fist }}$. Equation (7) will give consistent estimates only if $\operatorname{cov}\left[\left(\widetilde{B}_{i t}, \widetilde{\text { control }} l_{i t}\right), \tilde{\mu}_{i}+\widetilde{\omega}_{s}+\widetilde{\theta}_{t}\right]=0$, which is a condition that is unlikely to hold since $\widetilde{B}_{i t}$ are likely to be correlated across neighboring sites, meaning that it also be likely to be correlated with unobserved time-varying local effects and hence violating the orthogonality condition. As consequence, this paper will estimate equation (6) in aggregate level i.e provincial level.

Aside from that, this paper will also put emphasis on spatial issues, in essence that the baseline results will be divided into two geographical area which is categorized as Western part of Indonesia and Eastern part region of Indonesia. The rationale behind this strategy is firms are generally located in the Western part of Indonesia, in particular Java and Sumatera islands. Also, by dividing the region into these two categories we will be able to test whether a relative concentrated industrialized region have a different impact in term of the access to the financial services as proxied by branch density. Following Fafchamps and Schündeln (2013), the hypothesis in this study is as follow, small firms in locations where number of banks branches $(B I)$ are relatively high and financially less constrained therefore can grow faster.

\section{METHODOLOGY}

\subsection{Data, Variable, and Proxies}

The brief description and definition regarding the variables and its sources are provided on the table. The main source of our data is Survey on Manufacturing Industry, Indonesian Statistical Bureau, and Bank Indonesia.

Following the same approach by Fafchamps and Schündeln (2013) and Burgess and Pande (2005), variable access to financial services will be proxied by the number of bank branches. As pointed by by Burgess and Pande (2005), bank branch can be used as prompt indicator as they found that branch expansion into previously unbanked area in India had given a significant impact particularly to the reduction of poverty in the rural area. The finding also suggest that the Central Bank's licensing policy could enabled the development of an extensive rural branch network, and this, in turn, allowed rural households to accumulate more capital and to obtain loans for longer-term productive investment. 
We measure the performance of the firm using three indicators; value added, output, and employment. However, according to by Fafchamps and Schündeln (2013), value added is a more satisfying proxy for growth opportunities since it measures returns to labor and capital. On the other hand, Fisman and Love (2007) argue that sales have less measurement error: sales are measured directly in the census, while value added is constructed from several variables. The same can be said for employment. Given that, over our study period, employment, sales, and value added moved in different directions, this study will elaborate all of these three indicators.

In order to taken into account firm characteristics issues, this study will put emphasize on small-medium firm performance. Generally, the small-scale industrial enterprises tends to group together by geography and by economic subsector (Berry, Rodriguez and Sandee, 2001). Furthermore, they also pointed out that small-medium firms has an important role as the locus of most labor absorption in Indonesian manufacturing industries.

This study will also put several control variables in order to capture the quality of economic development. As many previous study showed and argue, level of socioeconomic conditions need to represent some aspects of quality of life such as education, poverty, infrastructure, living standards, and employment (Fafchamps and Schündeln (2013), Guiso, Sapienza and Zingales (2004), Djankov et al., (2007), Japelli and Pagano (2002) and Petersen and Rajan, (2002)). Furthermore, as argued by Djankov et al., (2007), Japelli and Pagano (2002) and Petersen and Rajan, (2002), lenders would be more willing to deal with borrowers if they are well informed. The problem of asymmetric information and transaction cost considerations suggest that physical distance between lender and borrower is likely to affect access to finance. Hence, in the socioeconomically less developed regions banks have less incentives to the financial outreach as the information as well as the quality of borrowers are inadequate. Indeed, borrowers' actions are harder to observe when lender and borrower are far apart, leading to adverse selection (of potential borrower) and moral hazard (for current borrower). Guiso, Sapienza and Zingales found (2004) found that social capital plays an important role in the degree of financial development across different parts of Italy. In line with this condition, this study believes that major control factor should potentially help to explain the interplay between firm performance and access to the financial services at the provincial level in Indonesia.

Related to the growth opportunity, technological opportunities across sectors can vary significantly. ${ }^{9}$ To take into account this factors, we follow similar procedure of Fafchamps and Schündeln (2013) in calculating the sectoral growth opportunities $\left(G_{s}=\log (\operatorname{sum}(\operatorname{vad} 2013))-\right.$ $\log (\text { sum(vad2010) })^{10}$. The key assumption is that large firms are less likely to be financially constrained, and therefore are more able to take advantage of growth opportunities in their sector. See Guiso et al. (2004) for a similar assumption, which is based on findings by Berger et al. (2005) and Petersen and Rajan (2002).

9 Industrial Development Report 2016 (see reference)

10 The report s of growth opportunities calculation showed by the Table 3 in appendix. This study found a considerable variation across sectors over the sample period. 


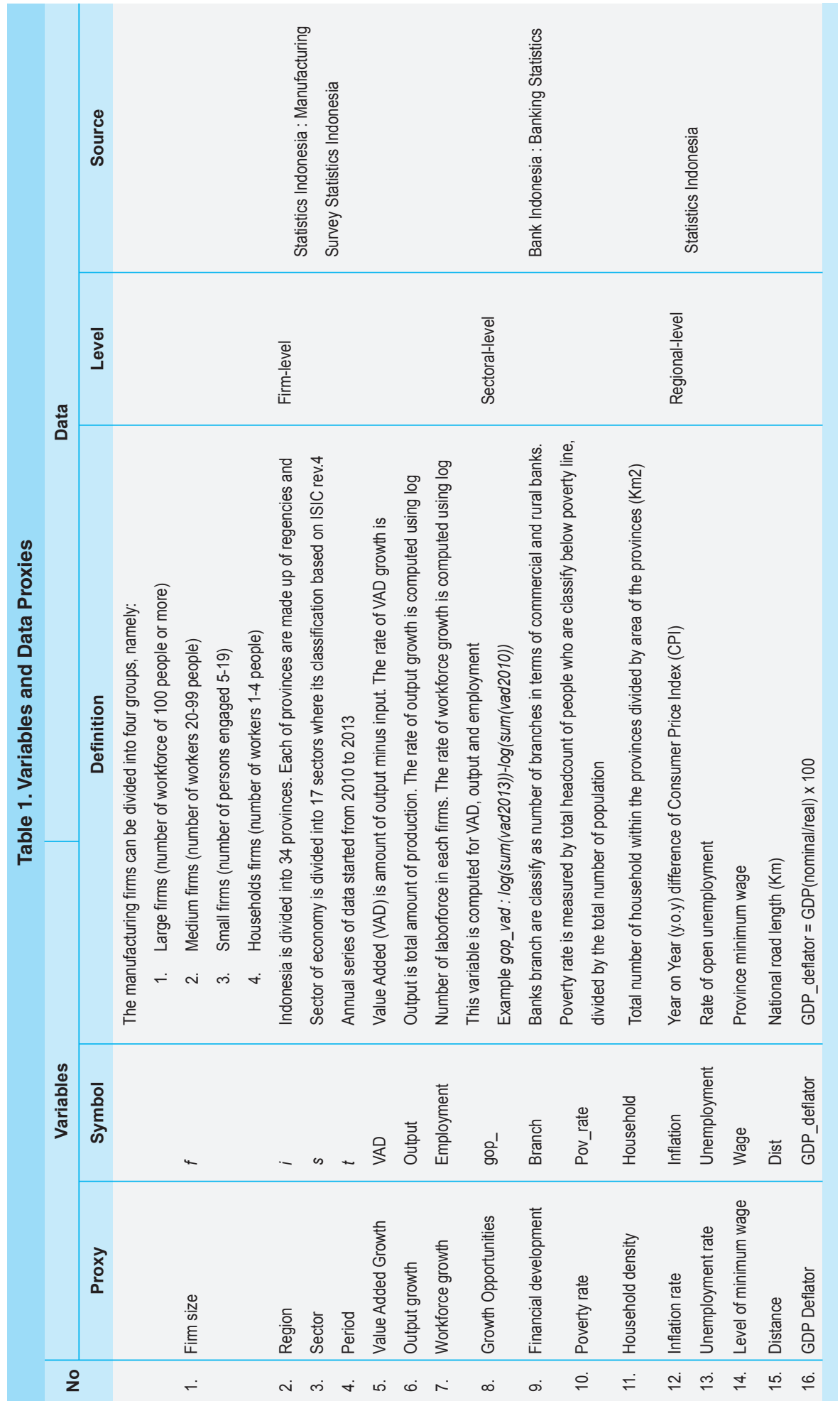


However, unlike Fafchamps and Schündeln (2013), this paper only use two possible cut-off point in identifying less constrained firms. First, firm size indicator, a firms which has threshold with at least 100 employees is categorized as big firms. Second, foreign ownership, complement with the manufacturing firm size, firms with more threshold than $50 \%$ in the foreign ownership is identified as big firms. The logic behind this threshold is foreign firms are less likely to be constrained by local financial markets. For simplicity purposes, less constrained firms will then label as big firms and firms that has workforce below 100 employees will be label as small firms.

\subsection{Estimation}

We use panel data estimation on this paper. As stated previously on Chapter 2, the empirical model constructed should pay attention to several possible bias, particularly the endogeneity problem. Endogeneity problem occurs when an explanatory variable is correlated with the error term. This endogeneity bias can arise as a result of measurement error, autoregression with auto correlated errors, simultaneity and omitted variables. Two common causes of endogeneity are an uncontrolled confounder causing both independent and dependent variables of a model, and a series loop of causality between the independent and dependent variables of a model (see Hill, Griffths and Lim, 2012). ${ }^{11}$

Our empirical model is potentially suffered from the endogeneity problem. Banks may locate in regions, sectors or places that are expected to grow faster and hence where firms should perform better. To deal with this issue, we follow Fafchamps and Schündeln (2013) and use the local bank availability measured at $t-1$ period as a proxy for the individual firm's access to financing.

The above approach to deal with endogeneity bias is similar with Rajan and Zingales (1998). The main advantage of this approach is it allows us to control the location-specific growth trend, the expectation of which may have influenced bank placement. Rajan and Zingales (1998) documented that because of structural or technological reasons, there is variation across sectors in how much firms in as sector have to rely on external funds.

Subsequent work by Fisman and Love (2007) provides reinterpretation of the original findings by Rajan and Zingales (1998). They argue that the test by Rajan and Zingales (1998) is implicitly a test about whether financial development facilitates firms' investment in the presence of growth opportunities. Keeping production unchanged only requires replacement investment, which can typically be financed out of retained earnings. In contrast, if there are opportunities for growth, firms will need for expansion purposes. If funds cannot be found

11 R.C. Hill, W.E. Griffths, G.C. Lim, 2012. Principles of Econometrics, John Wiley \& Sons, Inc., Chapters 10,11 
rapidly, opportunities will be seized by others. This mean that access to external finance is most critical for firms that face growth opportunities.

Another important issue during the estimation is the reverse causality. In firm-level, the correlation between performance and access to finance is subject to reverse causation since banks are expected to lend to firms with high performance and prospects. To deal with this reverse causality issues, we follow the same strategy proposed by Fafchamps and Schündeln (2013). In short, in order to measure business activity within the regions, model (6) are only estimated for small firms and exclude the big ones. The idea behind this strategy is following. Among the possible theoretical reasons for larger firms' better access to external financing are, for instance information issues, in a way that it is less costly for banks to obtain reliable and/ or independent information about larger firms' income statements or balance sheets because information issues (less asymmetric information) and has to be collected by banks over time through relationship with firms (Petersen and Rajan, 2002).

\section{RESULT AND ANALYSIS}

\subsection{Descriptive Statistics}

This study use matching technique by firm establishment ID in merging the firm-level dataset with the regional-level dataset in order to obtain a panel dataset. For the purpose of analysis, if the data is missing and discontinue in the firm-level data, then it is remove from the sample. After merging the data set, the total observations is 43,855 or reduced by $48 \%$ due to the missing data at firm-level category over 2010-2013.

In general, within the big firms category, the data show a straight upward trend value added. Meanwhile small firms exhibited a relative stagnant performance in compare to the big firms particularly in post 2011. At some point, this condition will be beneficial for this study due to the fact that this trend will generate an upward growth opportunities for small performance as framed by empirical previous study (Fafchamps and Schündeln (2013), Fisman and Love (2007)).

As recorded in the Indonesian manufacturing firm survey 2013, of the total number 23,678 manufacturing firms, 70\% are belong to the Micro-Small-Medium Enterprise (MSME) category. Now, If we closely examine within region as showed by Figure 3 on the right, we can see a clear evidence that number of firms that are located in the Western part of Indonesia is considerably higher than Eastern part of Indonesia (see grey shaded area). This condition support the empirical strategy in this paper in term of examining the impact of firms access between these two geography area. 


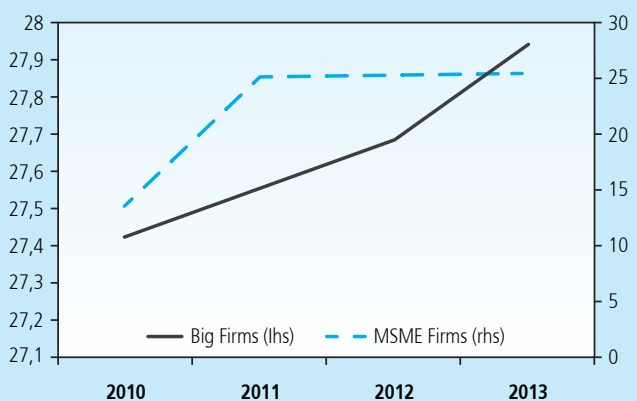

Source : author calculation

Figure 2. Trend of Firms Performance (log of sum(VAD)) in Indonesia over 2010-2013

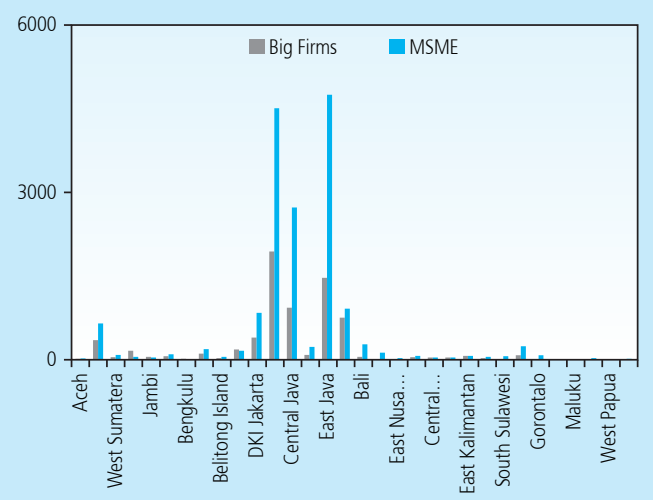

Source : author calculation

Figure 3. Number of Firms by Province in 2013

In general, from descriptive statistics analysis (Appendix 1), this paper found that firm's performances are generally lower in MSME category. This phenomenon can be seen from the mean of growth rate in the MSME category that are proxied by value added (VAD), output and employment. From all of these three main indicators of firm performance, MSME always exhibited a lower value than the big firms. For instance, over the period 2010-2013, the mean of VAD growth in the MSME category is 0.10 . In contrast, mean of VAD growth rate of big firms are considerable more than twice in which recorded at 0.24 over the same period. The VAD-less growth phenomenon in MSME probably cannot be separated from the fact that these firms exhibited a lower mean of growth in output and employment over the sample period.

Aside from this condition, the descriptive statistics show an important information regarding to the potential outlier problem as can be seen from the standard deviation in several variables such as branch density, population density and household density. ${ }^{12}$ In order to deal with this problem, this study compute DF-BETA threshold and check whether the variables above or below the threshold ${ }^{13}$. After carefully examining this method, a sample data than can be identified as an outlier is DKI Jakarta provinces.

Table 1 reports the correlation matrix of all variables for Western part and Eastern part of Indonesia. As already explained in the methodology section previously, big firms are excluded

12 These variables are belong to the same provinces i.e DKI Jakarta. In line with this condition, this study then remove DKI Jakarta province from the estimation.

13 DF-BETA figure for all region are reported in Appendix 7. DF-BETA absolute threshold for 43,855 observations is 0.0095 . This values is computed using +/- 2/sqrt(N). This study also use Variance Inflation Factors (VIF) test to detect severity in multicollinearity issues (Appendix 9). Explanatory variables that are potentially triggerd a high VIF then remove from the subsequent estimation i.e. Ihousehold and Idist. 


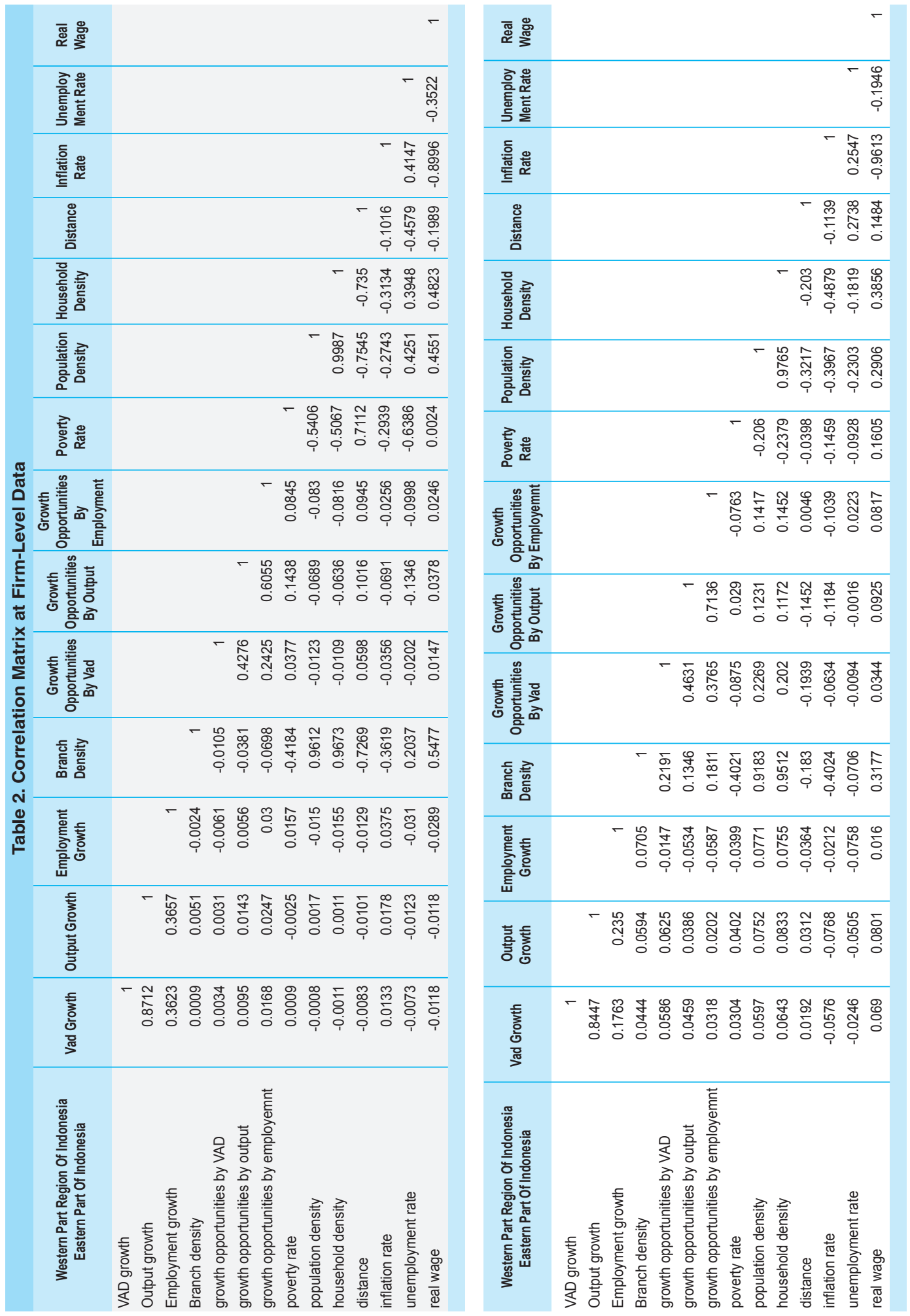


in this correlation matrix in order to avoid estimation biased. Based on Table 1 below, the main variable of interest show a positive correlation with all of the three firm performance indicators. However, the coefficient correlation is relatively weak in the Western part of Indonesia. Moreover, from Table 1, the correlation between growth opportunities $\left(G_{s}\right)$ are positive across Western part of Indonesia except with value added growth opportunities with employment growth $(-0,0061)$. A negative correlation indicates that if the number of workforce in the big firms is increasing then it will have a negative impact in small firms performance.

Furthermore, branch density in general has positive correlation with firm performance. However the correlation magnitude tends to be weaker in Western part of Indonesia in compare to Eastern part. Growth opportunities have positive correlation on firm performance over the sample period although the magnitude is not so strong. Furthermore, this study find a relative small negative correlation on growth opportunities by value added to employment growth. This phenomenon indicates that big firm performance can trigger a labor dynamics i.e. labor movement from small to big firms.

Branch density has negative correlation with poverty rate, meaning that the more regions has poverty rate the less branch would available. This phenomenon also supported by the correlation between real minimum wages and branch density which show positive correlation. In this case, richer provinces would have higher number of bank branches in compare to less rich provinces.

Branch density has negative correlation with distance. The farther distance with household, the less number of bank branches available. Problem of asymmetric information captured from this correlation in essence that lenders would be willing to deal with borrowers if they are well informed. This evidence is in line with previous study by Fafchamps and Schündeln (2013), Djankov et al., (2007), Amable \& Chatelain (2001). Also, the correlation matrix in the Table 1 shows that branch density and Inflation rate are negatively correlated, an indication that inflation represent a cost for Indonesian manufacturing firms.

\subsection{Firm-Level Estimations}

\subsubsection{Baseline Result}

Table 2 reports the baseline results for the four considered outcomes at the firm-level sample. We start using the value added growth as dependent variable $\left(\Delta Y f_{\text {ist }}\right)$, and then the branch density $\left(B_{i t}\right)$ and growth opportunities $\left(G_{s}\right)$. The latter is calculated from the less constrained firms, hence this results already exclude big firms in the estimation sample.

Based on the Table 2, the coefficient of interaction terms between branch density and growth opportunities (Ibranch_gopvad) is not significant. The goodness of fit of the model is considerably low or close to zero for every scenario, even after we try to control for endogeneity bias and using fixed-effect terms to control time-invariant factors. 
If we separate this interaction terms, the coefficient of branch density at $t-1$ is positive and statistically significant in affecting firm performance. However, this condition only appears to be important in the Western part of Indonesia and not in Eastern one. Possible explanation to this case is many of the small firms are concentrated in the well-connected region of Western Indonesia.

The magnitude of this coefficient is 1.49 for Western Indonesia; meaning a one percent point increase of the branch density will increase the firm performance by $1.49 \%$. In this firm level estimation, the growth opportunities is not statistically different from zero.

\begin{tabular}{|c|c|c|c|c|c|c|c|c|c|c|c|c|}
\hline \multirow{3}{*}{ Variables } & \multicolumn{4}{|c|}{ All regions } & \multicolumn{4}{|c|}{ Western Part of Indonesia } & \multicolumn{4}{|c|}{ Eastern Part of Indonesia } \\
\hline & \multicolumn{2}{|c|}{ Pool } & \multicolumn{2}{|c|}{ Fixed Effect } & \multicolumn{2}{|c|}{ Pool } & \multicolumn{2}{|c|}{ Fixed Effect } & \multicolumn{2}{|c|}{ Pool } & \multicolumn{2}{|c|}{ Fixed Effect } \\
\hline & (1) & (2) & (3) & (4) & (1) & (2) & (3) & (4) & (1) & (2) & (3) & (4) \\
\hline \multirow[t]{2}{*}{ Ibranch_gopvad } & -0.0876 & -0.347 & -0.259 & -0.261 & -0.0550 & -0.319 & -0.182 & -0.186 & 0.355 & 0.865 & -0.323 & -0.409 \\
\hline & $(0.0607)$ & $(0.279)$ & $(0.272)$ & $(0.270)$ & $(0.0780)$ & $(0.491)$ & $(0.482)$ & $(0.476)$ & $(0.407)$ & (1.598) & $(2.984)$ & (2.953) \\
\hline \multirow[t]{2}{*}{ Ibranch1 } & 0.0543 & $0.715^{* \star *}$ & $0.659^{* * *}$ & $1.285^{* * *}$ & 0.0321 & $0.692^{* *}$ & $0.603^{*}$ & $1.493^{* * *}$ & -0.170 & -0.00298 & 0.809 & 0.120 \\
\hline & $(0.0397)$ & $(0.217)$ & $(0.214)$ & $(0.379)$ & $(0.0514)$ & $(0.342)$ & $(0.338)$ & $(0.450)$ & $(0.254)$ & $(1.167)$ & (1.941) & $(2.117)$ \\
\hline \multirow[t]{2}{*}{ gop_vad } & -0.286 & -1.800 & -1.379 & -1.355 & -0.174 & -1.710 & -0.772 & -0.747 & 2.671 & 7.032 & -1.177 & -2.258 \\
\hline & $(0.226)$ & $(1.096)$ & (2.215) & (2.201) & $(0.283)$ & $(1.793)$ & $(2.784)$ & $(2.756)$ & (2.596) & (11.53) & (18.83) & (18.70) \\
\hline \multirow[t]{2}{*}{ Constant } & $0.280^{*}$ & $3.129^{\star \star \star}$ & $2.998^{* *}$ & $5.388^{\star * *}$ & 0.203 & $3.003^{* \star}$ & 2.529 & $5.840^{\star * *}$ & -1.252 & -0.990 & 4.899 & 0.924 \\
\hline & $(0.148)$ & $(0.847)$ & (1.437) & $(1.889)$ & $(0.187)$ & $(1.250)$ & (1.799) & (2.119) & $(1.636)$ & $(8.250)$ & (12.55) & (13.69) \\
\hline Observations & 17,844 & 17,844 & 17,844 & 17,844 & 17,138 & 17,138 & 17,138 & 17,138 & 706 & 706 & 706 & 706 \\
\hline R-squared & 0.000 & 0.001 & 0.004 & 0.004 & 0.000 & 0.001 & 0.004 & 0.005 & 0.006 & 0.003 & 0.008 & 0.019 \\
\hline Number of id & & 6,458 & 6,458 & 6,458 & & 6,194 & 6,194 & 6,194 & & 264 & 264 & 264 \\
\hline region $\mathrm{FE}$ & & yes & yes & yes & & yes & yes & yes & & yes & yes & yes \\
\hline sector FE & & & yes & yes & & & yes & yes & & & yes & yes \\
\hline time FE & & & & yes & & & & yes & & & & yes \\
\hline
\end{tabular}

\subsubsection{Additional Controls for the Level of Development}

Afterwards, this study also investigate whether the local financial development as proxied by branch density also come hand in hand with level of economic development, in particular in the Western part of Indonesia. Table 3 below reports the estimation results. As a direct measure of the level of development, this study put emphasis on several variables such as the poverty rate (pov_rate), i.e. the proportion of the population living below the poverty line, inflation rate (inflation), real minimum wages (Irwage), unemployment rate (unemployment) and household density (Ihousehold). 
Once again, after estimating with several control of level of development, this study do not find significant result on the interaction variables (Ibranch_gopvad) as empirically find for the case of Morocco in previous study by Fafchamps and Schündeln (2013). However, Table 3 provides an interesting insight for Indonesian case. At some point, after controlling timeinvariant factors, this study find that the level of development are closely connected with the level of branch density as can be seen from the stable increase in its magnitude when control variables are added into the core equation (6).

This study also estimates equation for the case of the Eastern part of Indonesia and find that many of explanatory variables are not statistically significant even after controlling for fixed-effect factors ${ }^{14}$. Also from the Table 3, we can see that poverty rate (pov_rate) has the highest magnitude for all specification for all outcome scenario (column (2) to (6)). For instance, in column (6), if poverty rate in this region increase by one percentage point, the firm performance will decrease by $12.37 \%$. Furthermore, real wages also has a significant and negative impact on firm performance during sample period. The coefficient on this variables is -5.21, meaning that an increase one percentage point in real wages will trigger a reduction in small performance by $5.21 \%$ over the sample period ${ }^{15}$. Another important variables that also significantly affected small firm performance is inflation rate (inflation). A one percentage point increase in inflation will decrease small firm performance by $0.45 \%$. From this overall situation, this imply that small firm expansion within Indonesian provinces is closely connected with level of economic development i.e. inequality problems. Taken these empirical findings together, this indicates that level of economic development within regions are matter most than financial access on small firm performance. These empirical findings are contrast compare to the case for Morocco (Fafchamps and Schündeln, 2013), where most of these variables are not statistically significant after controlling fixed effect for commune and sector level ${ }^{16}$.

14 In order to save the space in this report, this results is reported in Appendix 3.

15 According to Priasto (2015), income and consumption inequality in Indonesia have been steadily increasing since 2000. After recovering from the 1997-1998 Asian financial crisis, Indonesia experienced a period of strong economic growth, driven in part by a commodities boom and strong domestic consumption. However, during this period the Gini coefficient also climbed in 2000 from 0.31 to 0.43 by 2013. These condition has made significant contribution to a high inequality within the country.

16 See page 20 on Table 3. Robustness : other controls for level of economic development in Fafchamps and Schündeln (2013) 


\begin{tabular}{|c|c|c|c|c|c|c|}
\hline \multicolumn{7}{|c|}{$\begin{array}{c}\text { Table } 4 . \\
\text { Estimation Firm Performance (Value Added Growth)at Firm-Level in Western Part of Indonesia }\end{array}$} \\
\hline Variables & (1) & (2) & (3) & (4) & (5) & (6) \\
\hline Ibranch_gopvad & $\begin{array}{l}-0.186 \\
(0.476)\end{array}$ & $\begin{array}{r}-0.198 \\
(0.472)\end{array}$ & $\begin{array}{r}-0.208 \\
(0.475)\end{array}$ & $\begin{array}{r}-0.229 \\
(0.471)\end{array}$ & $\begin{array}{r}-0.230 \\
(0.469)\end{array}$ & $\begin{array}{l}-0.269 \\
(0.467)\end{array}$ \\
\hline Ibranch1 & $\begin{array}{r}1.493^{\star * *} \\
(0.450)\end{array}$ & $\begin{array}{r}1.764^{* * *} \\
(0.465)\end{array}$ & $\begin{array}{c}1.669^{* * *} \\
(0.479)\end{array}$ & $\begin{array}{c}1.411^{* * *} \\
(0.491)\end{array}$ & $\begin{array}{r}1.477^{\star * *} \\
(0.504)\end{array}$ & $\begin{array}{l}1.326^{* *} \\
(0.563)\end{array}$ \\
\hline gop_vad & $\begin{array}{r}-0.747 \\
(2.756)\end{array}$ & $\begin{array}{r}-0.814 \\
(2.749)\end{array}$ & $\begin{array}{r}-0.825 \\
(2.748)\end{array}$ & $\begin{array}{r}-0.876 \\
(2.735)\end{array}$ & $\begin{array}{r}-0.899 \\
(2.730)\end{array}$ & $\begin{array}{l}-1.034 \\
(2.724)\end{array}$ \\
\hline pov_rate & & $\begin{array}{l}-8.564^{*} \\
(4.374)\end{array}$ & $\begin{array}{r}-9.724^{* *} \\
(4.430)\end{array}$ & $\begin{array}{r}-11.37^{* *} \\
(4.496)\end{array}$ & $\begin{array}{r}-10.83^{\star *} \\
(4.530)\end{array}$ & $\begin{array}{r}-12.37^{* * *} \\
(4.641)\end{array}$ \\
\hline inflation & & & $\begin{array}{r}-0.0242 \\
(0.0288)\end{array}$ & $\begin{array}{r}-0.462^{\star * *} \\
(0.156)\end{array}$ & $\begin{array}{r}-0.508^{* * *} \\
(0.168)\end{array}$ & $\begin{array}{r}-0.453^{* *} \\
(0.176)\end{array}$ \\
\hline inflation1 & & & $\begin{array}{c}-0.0374 \\
(0.0280)\end{array}$ & $\begin{array}{r}-0.0268 \\
(0.0285)\end{array}$ & $\begin{array}{r}-0.0213 \\
(0.0295)\end{array}$ & $\begin{array}{r}-0.0167 \\
(0.0297)\end{array}$ \\
\hline Irwage & & & & $\begin{array}{r}-5.305^{\star \star *} \\
(1.859)\end{array}$ & $\begin{array}{r}-5.604^{\star * *} \\
(1.908)\end{array}$ & $\begin{array}{r}-5.214^{\star * *} \\
(1.937)\end{array}$ \\
\hline unemployment & & & & & $\begin{array}{r}0.0205 \\
(0.0264)\end{array}$ & $\begin{array}{r}0.0106 \\
(0.0295)\end{array}$ \\
\hline Ihousehold & & & & & & $\begin{array}{r}0.459 \\
(0.411)\end{array}$ \\
\hline Constant & $\begin{array}{r}5.840^{\star \star *} \\
(2.119)\end{array}$ & $\begin{array}{r}7.920^{\star * *} \\
(2.337)\end{array}$ & $\begin{array}{r}8.198^{\star * *} \\
(2.385)\end{array}$ & $\begin{array}{r}15.27^{\star * *} \\
(3.408)\end{array}$ & $\begin{array}{r}15.87^{\star \star *} \\
(3.543)\end{array}$ & $\begin{array}{l}12.28^{* \star} \\
(5.189)\end{array}$ \\
\hline Observations & 17,138 & 17,138 & 17,138 & 17,138 & 17,138 & 17,138 \\
\hline R-squared & 0.005 & 0.005 & 0.005 & 0.006 & 0.006 & 0.006 \\
\hline Number of id & 6,194 & 6,194 & 6,194 & 6,194 & 6,194 & 6,194 \\
\hline region $\mathrm{FE}$ & yes & yes & yes & yes & yes & yes \\
\hline sector FE & yes & yes & yes & yes & yes & yes \\
\hline time FE & yes & yes & yes & yes & yes & yes \\
\hline
\end{tabular}

\subsubsection{Channel of Financial Access}

As we have seen from previous analysis, over the sample period, access to bank branches is not associated with faster growth for small firms in sectors with growth opportunities across provinces in Indonesia. However, the local bank availability has a positive impact on small firms performance. The question then is: how can firms achieve higher value added growth if local banks is available? The underlying assumption in the finance and growth literature is that access to finance can facilitates investment and that this, in turn, generates growth in value added by increasing capital and raising productivity. In line with this condition. This paper will attempt to test whether firms with better access to bank will increase their labor productivity 


\begin{tabular}{|c|c|c|c|}
\hline \multicolumn{4}{|c|}{$\begin{array}{l}\text { Table } 5 . \\
\text { Estimation Channel of Financial Access at Firm-Level in Western Part of Indonesia }\end{array}$} \\
\hline \multicolumn{4}{|c|}{ Channel of Financial Access } \\
\hline Dep. Variables & $\begin{array}{l}\text { Output } \\
\text { growth }\end{array}$ & $\begin{array}{l}\text { Employment } \\
\text { growth }\end{array}$ & $\begin{array}{c}\text { Labour } \\
\text { Productivity }\end{array}$ \\
\hline Ibranch_gop & $\begin{array}{r}0.135 \\
(0.166)\end{array}$ & $\begin{array}{r}-0.398^{\star *} \\
(0.162)\end{array}$ & $\begin{array}{l}0.133^{\star * \star} \\
(0.0499)\end{array}$ \\
\hline Ibranch1 & $\begin{array}{r}0.822^{*} \\
(0.436)\end{array}$ & $\begin{array}{r}1.322^{* * *} \\
(0.156)\end{array}$ & $\begin{array}{r}-0.119 \\
(0.0835)\end{array}$ \\
\hline gop_ & $\begin{array}{r}0.143 \\
(1.143)\end{array}$ & $\begin{array}{r}-1.240 \\
(0.763)\end{array}$ & $\begin{array}{r}0.838^{* * *} \\
(0.325)\end{array}$ \\
\hline pov_rate & $\begin{array}{r}-11.08^{* * *} \\
(4.195)\end{array}$ & $\begin{array}{r}-1.765 \\
(1.417)\end{array}$ & $\begin{array}{l}-1.620^{*} \\
(0.889)\end{array}$ \\
\hline inflation & $\begin{array}{r}-0.637^{* * *} \\
(0.148)\end{array}$ & $\begin{array}{r}0.0736 \\
(0.0536)\end{array}$ & $\begin{array}{r}-0.00135 \\
(0.00486)\end{array}$ \\
\hline inflation1 & $\begin{array}{r}0.0103 \\
(0.0278)\end{array}$ & $\begin{array}{r}-0.0298^{* * *} \\
(0.0100)\end{array}$ & $\begin{array}{r}-0.116^{* * *} \\
(0.0326)\end{array}$ \\
\hline Irwage & $\begin{array}{r}-7.216^{\star * *} \\
(1.700)\end{array}$ & $\begin{array}{r}1.021 \\
(0.625)\end{array}$ & $\begin{array}{r}-0.00190 \\
(0.00517)\end{array}$ \\
\hline unemployment & $\begin{array}{r}0.0347 \\
(0.0234)\end{array}$ & $\begin{array}{l}0.0245^{\star * *} \\
(0.00735)\end{array}$ & $\begin{array}{r}-1.222^{\star \star \star} \\
(0.373)\end{array}$ \\
\hline Constant & $\begin{array}{c}8.882^{*} \\
(4.587)\end{array}$ & $\begin{array}{r}2.160 \\
(1.418)\end{array}$ & $\begin{array}{r}4.410^{\star * *} \\
(0.669)\end{array}$ \\
\hline Observations & 17,138 & 17,138 & 17,138 \\
\hline R-squared & 0.007 & 0.039 & 0.048 \\
\hline Number of id & 6,194 & 6,194 & 6,194 \\
\hline region $\mathrm{FE}$ & yes & yes & yes \\
\hline sector FE & yes & yes & yes \\
\hline time FE & yes & yes & yes \\
\hline
\end{tabular}

and output. According to Fafchamps and Schündeln (2013), in case of investment in labor saving equipment, it is also conceivable that value added rises but output remains unchanged.

Table 4 reports the estimation result for channel of financial access at firm level in Western part of Indonesia. This study follow the same procedure by dividing the channel into two main category, i.e. output and employment growth. However, this paper do not put emphasis on investment channel due to the information that is not available on the dataset. This study find similar finding with Fafchamps and Schündeln (2013), as reported by the Table 4, the channel in which access to financial services is works through labor productivity. ${ }^{17}$ From the estimation, the impact of branch is positive to the output growth, while the impact on employment is negative, if we estimated the sum of these two impact, this will channel to the higher growth in the productivity. This finding is confirmed by the significancy of positive coefficient on the interaction variables which has a magnitude 0.133 as reported in Table 4.

17 In this study, labour productivity is measured using basic calculation i.e. output per employment. 
This empirical finding is probably due to the investment in machine and/or productive equipment whereas also found as well in the case of Morocco by Fafchamps and Schündeln (2013). When small firms has a better access to the banking institutions, firms potentially will make an investment in productive assets. Essentially, if small firms has a better access to the financial services then firms will channel the capital (loan from the banking institutions) on asset productivity in order to achieve higher level performance as confirmed by this empirical findings within Indonesia provinces. Table 4 also indicates that if level of economic development such as inflation rate, poverty rate and unemployment rate are strongly connected with the small firm performance. In general, this study generally find that level of socioeconomic development in Indonesia are negatively link to small firm performance, for instance a higher in inflation rate will make an increase on marginal cost and therefore will lower small firms productivity. Taken these information with the previous analysis in subsection 5.1.2, generally this study find that level of economic development such as poverty and inflation is closely connected with the small firm performance.

\subsection{Regional-Level Estimation}

Table 5 reports the estimation results on regional level. In this subsection, we estimate equation (6) but using aggregated level data to perform robustness checks. In general, this study find that once estimating at a more aggregated level and after rule out the fixed-effect time invariant factors, the variable in interest remain insignificant. Also, the branch's density change its sign and no longer become significant with small firm performance, in particular for value added growth and output growth. But the branch density impact are statistically different from zero in term of the impact to growth of employment. ${ }^{17}$ Moreover, an important remarks can be seen from the positive sign of growth opportunities on the small firms performance within Western part of Indonesia. This mean that in sectors that has positive growth opportunities, small firms can make a business decision in to expand their activity within the Western part of Indonesia. The rationale behind these findings is when the small firms see a positive outlook in business opportunities, they will use financial institutions intermediation in order to grow their business, then it it will give an opportunities for small firms within the regions to enter the business related sectors.

17 After aggregating the sample into a regional-level, the number of observation reduce to 960 . Theoretically we should have 1,972 observations because the sample data on this study consist 29 provinces, 17 sectors and 4 times periods. However, all of provinces samples do not constantly consist 17 sectors and hence resulting a reduction in the total of number of observations when the samples are aggregated. 


\begin{tabular}{|c|c|c|c|}
\hline \multicolumn{4}{|c|}{$\begin{array}{l}\text { Table } 6 . \\
\text { Estimation at Regional-Level Firm Performance in Western Part of Indonesia }\end{array}$} \\
\hline \multicolumn{4}{|c|}{ Firm Performance } \\
\hline Variables & VAD growth & Output growth & Employment growth \\
\hline \multirow[t]{2}{*}{ Ibranch_gopvad } & -0.112 & 0.331 & 0.196 \\
\hline & $(0.467)$ & $(0.366)$ & $(0.131)$ \\
\hline \multirow[t]{2}{*}{ Ibranch1 } & -0.274 & -0.281 & $0.448^{\star * *}$ \\
\hline & $(0.847)$ & $(0.836)$ & $(0.152)$ \\
\hline \multirow[t]{2}{*}{ gop_vad } & $8.051^{* * *}$ & $5.832^{* * *}$ & $0.733^{* *}$ \\
\hline & $(2.188)$ & $(1.384)$ & $(0.329)$ \\
\hline \multirow[t]{2}{*}{ pov_rate } & -22.00 & -19.56 & -3.035 \\
\hline & $(13.36)$ & $(13.40)$ & (2.506) \\
\hline \multirow[t]{2}{*}{ inflation } & -0.329 & -0.654 & -0.189 \\
\hline & $(0.439)$ & $(0.466)$ & $(0.127)$ \\
\hline \multirow[t]{2}{*}{ Irwage } & -1.719 & -3.516 & $-2.141^{*}$ \\
\hline & $(4.561)$ & $(4.882)$ & (1.255) \\
\hline \multirow[t]{2}{*}{ unemployment } & -0.0660 & -0.0881 & -0.00953 \\
\hline & $(0.0757)$ & $(0.0746)$ & $(0.0150)$ \\
\hline \multirow[t]{2}{*}{ Constant } & 4.619 & 5.282 & 4.232 \\
\hline & $(9.737)$ & $(10.35)$ & (2.581) \\
\hline Observations & 564 & 564 & 564 \\
\hline R-squared & 0.188 & 0.226 & 0.161 \\
\hline region FE & yes & yes & yes \\
\hline sector FE & yes & yes & yes \\
\hline time FE & yes & yes & yes \\
\hline
\end{tabular}

Furthermore, from the Table 5, we can also draw another important implication related to the impact of financial access on firm performance. The coefficient of branch density (Ibranch1) on the employment growth is positive and statistically significant. This evidence indicates that if small firms have better access to the financial services, it only works through employment channel. This evidence is in line with the theoretical framework as proposed by Amable and Chatelain (2001), implying that when banks branch density within the region is increase, then small firms who has access to the financial services will channel their capital from banking institutions into a positive labor absorption in order to help country take off from poverty trap. 


\section{CONCLUSION}

This paper analyzes the impact of local financial development on firm performance across provinces in Indonesia. Combining data from the Indonesian survey of manufacturing firms with information from regional level data, the study empirically found two key findings.

First, we do not find consistent results that the local bank availability is robustly associated with faster growth for micro-small-medium firms in sectors with growth opportunities. This evidence is contrast with the previous study by Fafchamps and Schündeln (2013) in Morocco where the local bank availability was robustly associated with the firm located in sector with growth opportunities. Second, there are positive interplay between access to financial services and firm performance across Indonesian archipelago. However, this interplay only works significant within the western part region of Indonesia. Third, access to the financial service appears to be closely connected with the level of economic development, in particular rate of poverty and inflation within the western part region of Indonesia.

In regard to the channel to financial access, this study finds a significant link between the access to financial services and the productivity. In this case, small firms that have better access to finance will potentially make an investment in productive assets. Taken these empirical findings together suggest, this study imply that level of inequality across Indonesian archipelago need to be reduced in order not only to provide a better access of financial services to the local stakeholders but also to improve small firms performance through investment channel. 


\section{REFERENCES}

Amable, Bruno and Jean-Bernard Chatelain. (2001). Can Financial Infrastructures Foster Economic Development. Journal of Development Economics. 64, 481-498.

Beck,Thorsten, Asli Demirgüç-Kunt, Maria Soledad Martinez Peria. (2007). Reaching out : Access to and use of Banking Services Across Countries. Journal of Financial Economics. 85, 234-266.

Berry, Albert, Edgard Rodriguez and Henry Sandee. (2001). Firm and Group Dynamics in the Small Medium Enteprise sector in Indonesia. World Bank Institute.

Burgess, Robin and Rohini Pande. (2005). Do Rural Banks Matter ? Evidence from the Indian Social Banking Experiment. American Economic Review. 95 (3), 780-795.

Claessens, Stijn. (2006). Access to Financial Services : A review of The Issues and Public Policy Objectives. Oxford University Press.

Djankov, Simeon, Caralee Mcliesh and Andrei Shleifer. (2007). Private Credit in 129 Countries. Journal of Financial Economics. 84, 299-329.

Demirgüç-Kunt Asli, Lero Klapper, Dorothe Singer and Peer Van Oudheusden. (2014). The Global Findex Database 2014. Measuring Financial Inclusion around the World. Policy Research Working Paper 7255. World Bank.

Fafchamps, Marcel and Matthias Schündeln. (2013). Local financial Development and Firm Performance : Evidence from Morocco. Journal of Development Economics. 103, 15-28.

Fisman, Raymond and Inessa Love. (2007). Financial Dependence and Growth Revisited. Journal of The European Economic Association. 5 (2-3), 470-479.

Goldsmith, R. (1969). Financial Structure and Development. Yale Univ. Press, New Haven, CT.

Guiso, Luigi, Paola Sapienza and Luigi Zingales. (2004). Does Local Financial Development Matter?. Quarterly Journal of Economics. 119 (3), 929-969.

Hill, R. Carter, William E. Griffiths and Guay C. Lim. (2012). Principles of Econometrics, 4th Edition.

King, Robert and Levine Ross. (1993). Finance and Growth : Schumpeter Might be Right. Quarterly Journal of Economics. 108 (3), 717-737.

Levine, Ross. (1997). Financial Development and Economic Growth : Views and Agenda. Journal of Economic Literature. 30, 596-620.

Levine, Ross. (2005). Finance and Growth : Theory and Evidence. Chapter 12 Handbook of Economic Growth. Amsterdam : North-Holland Elsevier Pubslisher. 
Priasto, Aji. (2015). Summary of Indonesia's Povery Analysis. Asian Development Bank Papers No.04 October 2015.

Pagano, Marco and Tullio Jappelli. (2002). Information Sharing, Lending and Defaults. Crosscountry Evidence. Journal of Banking and Finance. 26, 2017-2045.

Petersen, Mitchell and Raghuram Rajan. (2002). Does Distance Still Matter ? The Information Revolution in Small Business Lending. Journal of Finance. 57 (6), 2533-2570.

Rajan, Raghuram G. and Luigi Zingales. (1998). Financial Dependence and Growth. American Economic Review. 88, 559-586.

Rosengard, Jay K. and Agustinus Prasetyantoko. (2012). Regulatory Constraints to Financial Inclusion in Indonesia. East Asia Forum : Economics, Politics and Public Policy in East Asia and The Pacific. (accessible from http://www.eastasiaforum.org/2012/06/11/ regulatoryconstraints-to-financial-inclusion-in-indonesia)

Subandono. (2015). Institutions, Croissance Economique et Entrepreneuriat: Causes et Conséquences des Activités Entrepreneuriales Sur Le Développement Économique des Regions Indonésiennes. These doctoral Universite Paris 1 Pantheon Sorbonne.

Soedarmono, Wahyoe, Iftekhar Hasan and Nuruzzaman Arsyad. (2015). Finance-Growth Nexus: Evidence from Indonesia. (http://papers.ssrn.com/sol3/papers.cfm?abstract_id=2570737)).

Trinugroho, Irwan, Agusman Agusman, Moch Doddy Ariefianto, Darsono Darsono, Amine Tarazi. (2015). Determinants of Cross Regional Disparity in Financial Deepening. Evidence from Indonesian Province. (accessible from https://hal-unilim.archives-ouvertes.fr/hal-01114255).

United Nations Industrial Development Organizations. (2015). The Role of Technology and Innovation in Inclusive and Sustainable Industrial Development.

World Bank. (2008). Finance for All : Policy Pitfalls in expanding access.

World Bank. (2014). The Global Findex 2014. Measuring financial access around the World (accessible from http://www.worldbank.org/en/programs/globalfindex). 


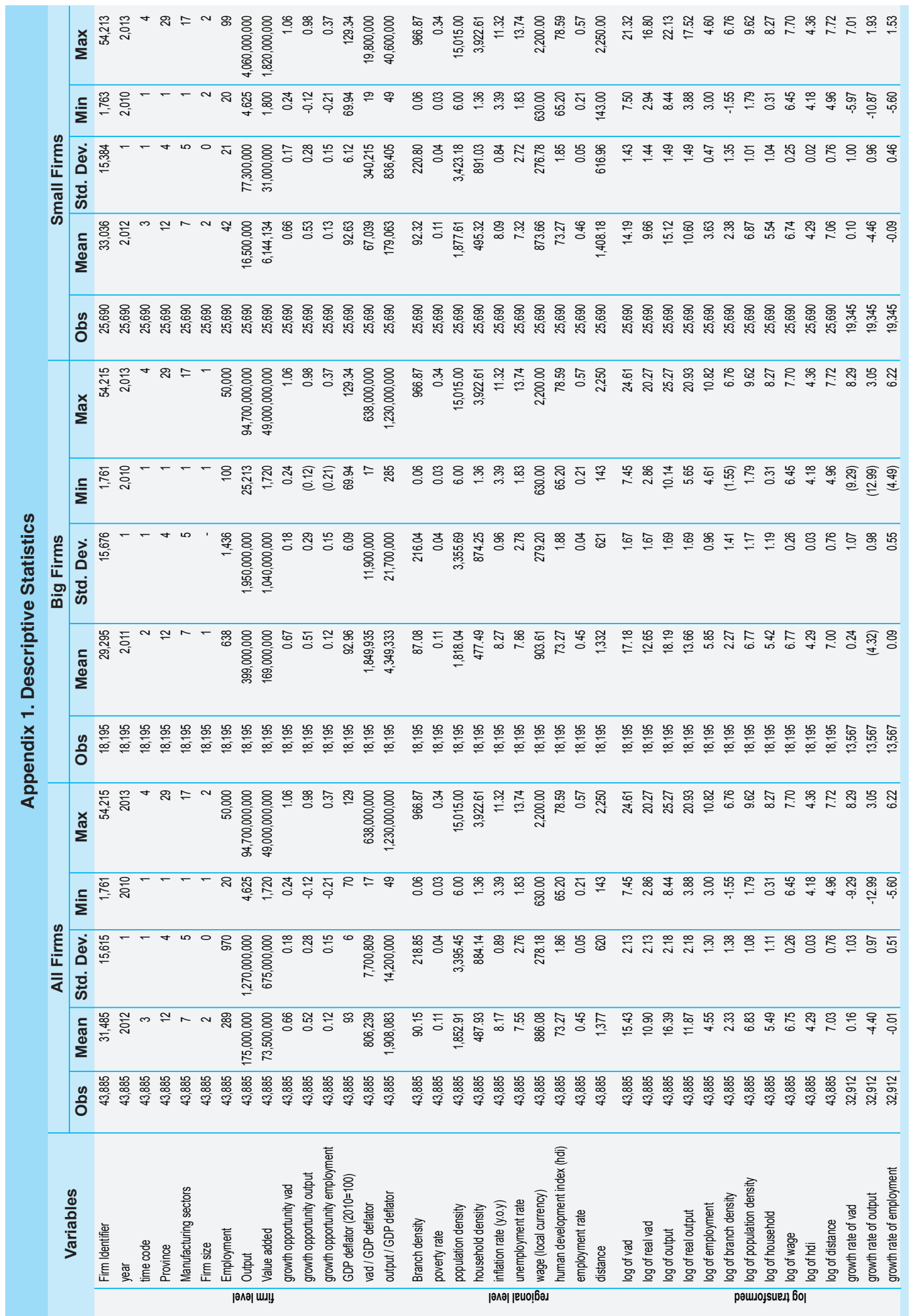




\begin{tabular}{|c|c|c|c|c|}
\hline \multicolumn{5}{|c|}{ Appendix 2: Growth Opportunities } \\
\hline \multirow{2}{*}{ No } & \multirow{2}{*}{ Sector } & \multicolumn{3}{|c|}{ Growth Opportunities } \\
\hline & & VAD & Output & Employment \\
\hline 1 & Food processing and beverages & 0.69 & 0.78 & 0.33 \\
\hline 2 & Tobacco & 0.83 & 0.70 & 0.12 \\
\hline 3 & Textiles & 0.94 & 0.63 & -0.04 \\
\hline 4 & Garment & 0.72 & 0.54 & 0.09 \\
\hline 5 & Leather & 0.74 & 0.63 & 0.14 \\
\hline 6 & Wood and wood products & 0.64 & 0.51 & 0.07 \\
\hline 7 & Paper and printing & 0.41 & 0.40 & 0.10 \\
\hline 8 & Coke and refined petroleum & 0.55 & 0.98 & 0.01 \\
\hline 9 & Chemical and pharmaceutical products & 0.75 & 0.85 & 0.19 \\
\hline 10 & Rubber and plastics products & 0.68 & $(0.12)$ & 0.00 \\
\hline 11 & Metal transformation & 0.58 & 0.23 & 0.08 \\
\hline 12 & Mechanical equipment & 0.85 & 0.87 & 0.37 \\
\hline 13 & Computer, communication and optical products & 0.49 & 0.46 & -0.03 \\
\hline 14 & Electrical equipment & 1.06 & 0.77 & 0.17 \\
\hline 15 & Transport equipment & 0.27 & 0.32 & 0.23 \\
\hline 16 & Furniture & 0.24 & 0.33 & -0.21 \\
\hline 17 & Repair machinery and recycling & 0.53 & 0.48 & 0.01 \\
\hline
\end{tabular}




\begin{tabular}{|c|c|c|c|c|c|c|}
\hline \multicolumn{7}{|c|}{ Appendix 3: Estimation at Firm-Level with Controls in Eastern Part of Indonesia } \\
\hline Variables & (1) & (2) & (3) & (4) & (5) & (6) \\
\hline Ibranch_gopvad & $\begin{array}{r}-0.409 \\
(2.953)\end{array}$ & $\begin{array}{r}-0.530 \\
(2.887)\end{array}$ & $\begin{array}{r}-0.518 \\
(2.822)\end{array}$ & $\begin{array}{r}-0.561 \\
(2.800)\end{array}$ & $\begin{array}{r}-0.704 \\
(2.773)\end{array}$ & $\begin{array}{r}-0.683 \\
(2.841)\end{array}$ \\
\hline Ibranch1 & $\begin{array}{r}0.120 \\
(2.117)\end{array}$ & $\begin{array}{r}1.001 \\
(2.297)\end{array}$ & $\begin{array}{r}0.933 \\
(2.285)\end{array}$ & $\begin{array}{r}1.022 \\
(2.262)\end{array}$ & $\begin{array}{r}1.381 \\
(2.269)\end{array}$ & $\begin{array}{r}1.525 \\
(2.326)\end{array}$ \\
\hline gop_vad & $\begin{array}{r}-2.258 \\
(18.70)\end{array}$ & $\begin{array}{r}-2.949 \\
(18.31)\end{array}$ & $\begin{array}{r}-2.882 \\
(17.88)\end{array}$ & $\begin{array}{l}-3.091 \\
(17.76)\end{array}$ & $\begin{array}{l}-3.837 \\
(17.60)\end{array}$ & $\begin{array}{l}-3.681 \\
(17.99)\end{array}$ \\
\hline pov_rate & & $\begin{array}{r}27.32 \\
(19.08)\end{array}$ & $\begin{array}{r}29.85 \\
(20.66)\end{array}$ & $\begin{array}{r}29.82 \\
(20.01)\end{array}$ & $\begin{array}{c}35.35^{*} \\
(20.75)\end{array}$ & $\begin{array}{r}29.10 \\
(20.53)\end{array}$ \\
\hline inflation & & & $\begin{array}{r}-0.0284 \\
(0.0708)\end{array}$ & $\begin{array}{r}0.164 \\
(0.182)\end{array}$ & $\begin{array}{r}0.112 \\
(0.170)\end{array}$ & $\begin{array}{r}0.144 \\
(0.168)\end{array}$ \\
\hline inflation1 & & & $\begin{array}{r}0.0485 \\
(0.0764)\end{array}$ & $\begin{array}{r}0.0560 \\
(0.0764)\end{array}$ & $\begin{array}{r}0.0418 \\
(0.0779)\end{array}$ & $\begin{array}{r}0.0543 \\
(0.0809)\end{array}$ \\
\hline Irwage & & & & $\begin{array}{r}1.313 \\
(1.162)\end{array}$ & $\begin{array}{r}1.231 \\
(1.105)\end{array}$ & $\begin{array}{r}1.347 \\
(1.088)\end{array}$ \\
\hline unemployment & & & & & $\begin{array}{r}0.0958 \\
(0.0613)\end{array}$ & $\begin{array}{r}0.0821 \\
(0.0621)\end{array}$ \\
\hline Ihousehold & & & & & & $\begin{array}{l}-1.322 \\
(1.442)\end{array}$ \\
\hline Constant & $\begin{array}{r}0.924 \\
(13.69)\end{array}$ & $\begin{array}{r}3.535 \\
(14.06)\end{array}$ & $\begin{array}{r}2.672 \\
(13.86)\end{array}$ & $\begin{array}{r}0.407 \\
(13.43)\end{array}$ & $\begin{array}{r}1.862 \\
(13.39)\end{array}$ & $\begin{array}{r}7.091 \\
(15.51)\end{array}$ \\
\hline Observations & 706 & 706 & 706 & 706 & 706 & 706 \\
\hline R-squared & 0.019 & 0.025 & 0.027 & 0.030 & 0.034 & 0.035 \\
\hline Number of id & 264 & 264 & 264 & 264 & 264 & 264 \\
\hline region FE & yes & yes & yes & yes & yes & yes \\
\hline sector FE & yes & yes & yes & yes & yes & yes \\
\hline time FE & yes & yes & yes & yes & yes & yes \\
\hline
\end{tabular}




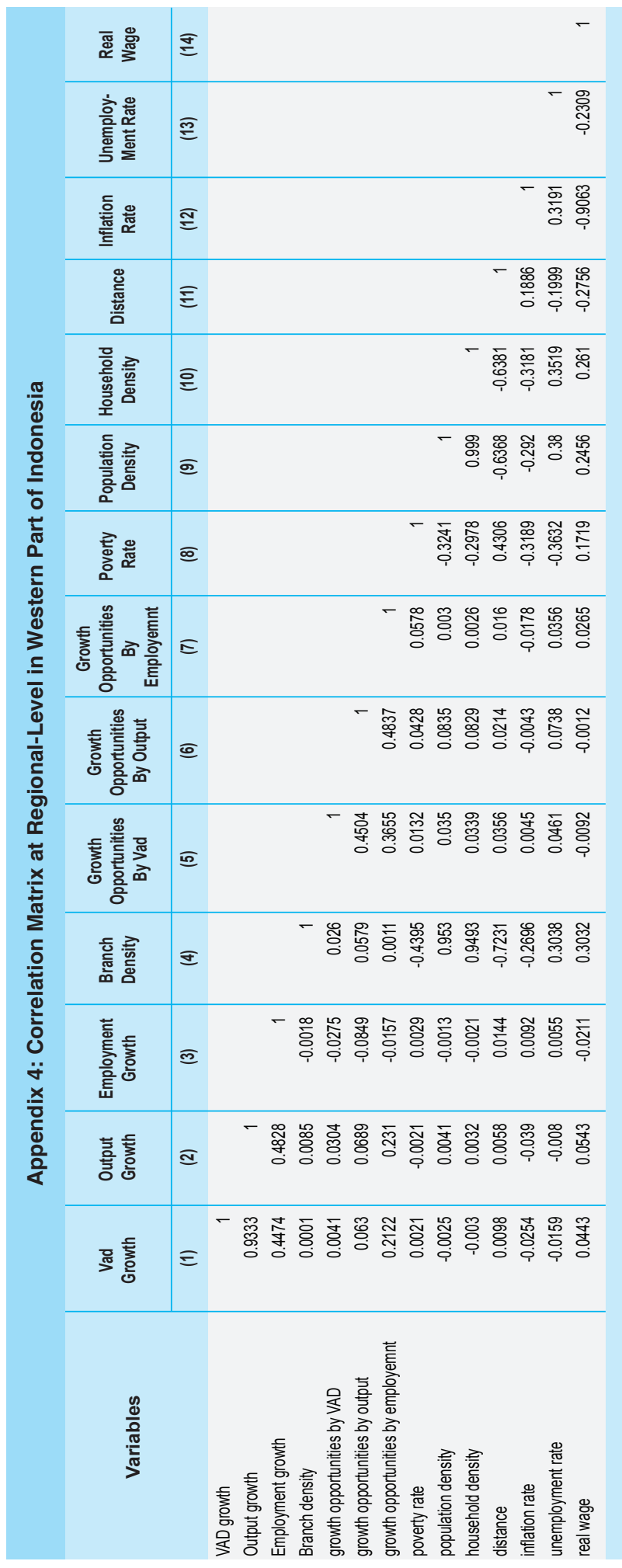




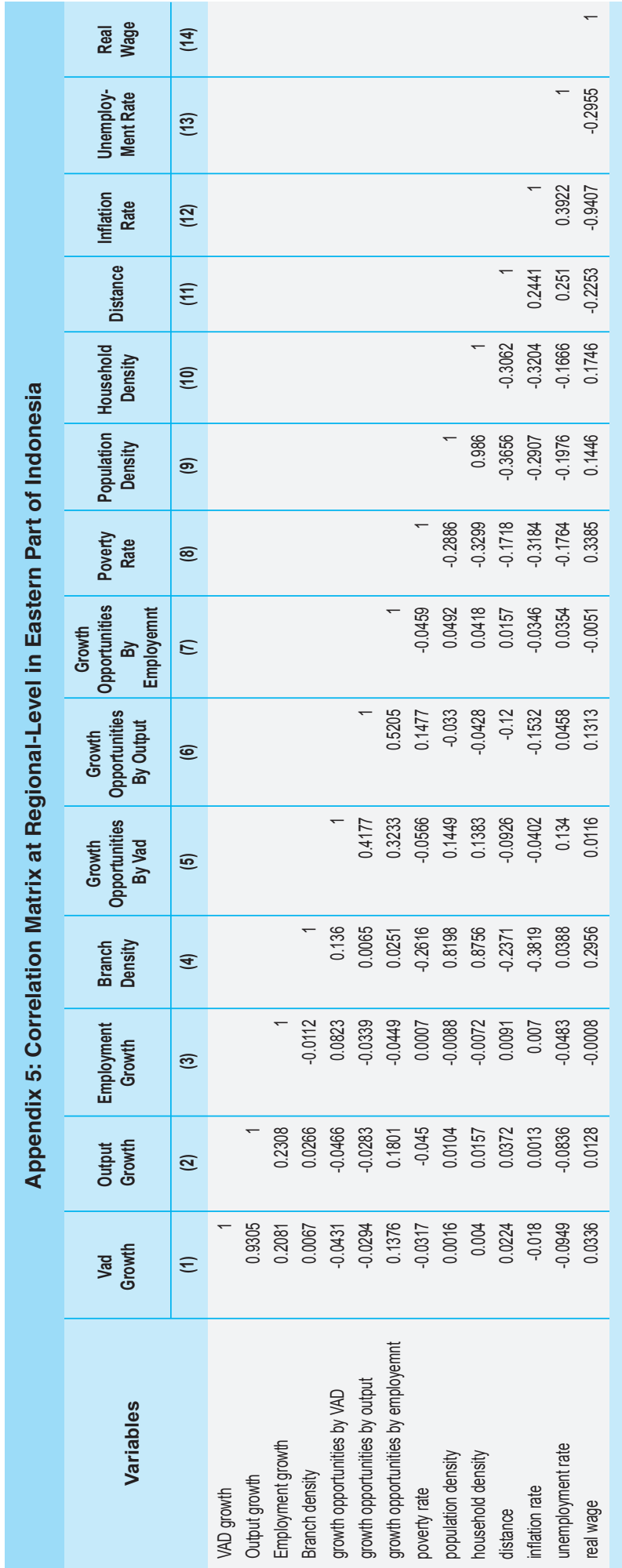




\begin{tabular}{|c|c|c|c|}
\hline \multicolumn{4}{|c|}{ Appendix 6: Estimation at Regional-Level in Eastern Part of Indonesia } \\
\hline \multirow{2}{*}{ Variables } & \multicolumn{3}{|c|}{ Firm Performance } \\
\hline & VAD growth & Output growth & Employment growth \\
\hline \multirow[t]{2}{*}{ Ibranch_gopvad } & -0.0135 & 0.375 & -0.212 \\
\hline & $(0.969)$ & $(0.618)$ & $(0.349)$ \\
\hline \multirow[t]{2}{*}{ Ibranch1 } & -0.627 & -0.449 & 0.363 \\
\hline & $(0.934)$ & $(0.817)$ & $(0.278)$ \\
\hline \multirow[t]{2}{*}{ gop_vad } & -1.351 & 0.891 & -0.701 \\
\hline & $(2.102)$ & (1.275) & $(0.469)$ \\
\hline \multirow[t]{2}{*}{ pov_rate } & -11.93 & -16.53 & 1.595 \\
\hline & (10.78) & (10.64) & (3.850) \\
\hline \multirow[t]{2}{*}{ inflation } & 0.309 & 0.307 & 0.0251 \\
\hline & $(0.246)$ & $(0.245)$ & $(0.0731)$ \\
\hline \multirow[t]{2}{*}{ Irwage } & 2.126 & 1.785 & 0.0607 \\
\hline & $(1.671)$ & $(1.737)$ & $(0.472)$ \\
\hline \multirow[t]{2}{*}{ unemployment } & $-0.152^{*}$ & $-0.155^{\star *}$ & -0.0365 \\
\hline & $(0.0818)$ & $(0.0746)$ & $(0.0251)$ \\
\hline \multirow[t]{2}{*}{ Constant } & -1.050 & -6.361 & -0.115 \\
\hline & (3.988) & (3.859) & (1.058) \\
\hline Observations & 264 & 264 & 264 \\
\hline R-squared & 0.200 & 0.247 & 0.123 \\
\hline region $\mathrm{FE}$ & yes & yes & yes \\
\hline sector FE & yes & yes & yes \\
\hline time FE & yes & yes & yes \\
\hline
\end{tabular}

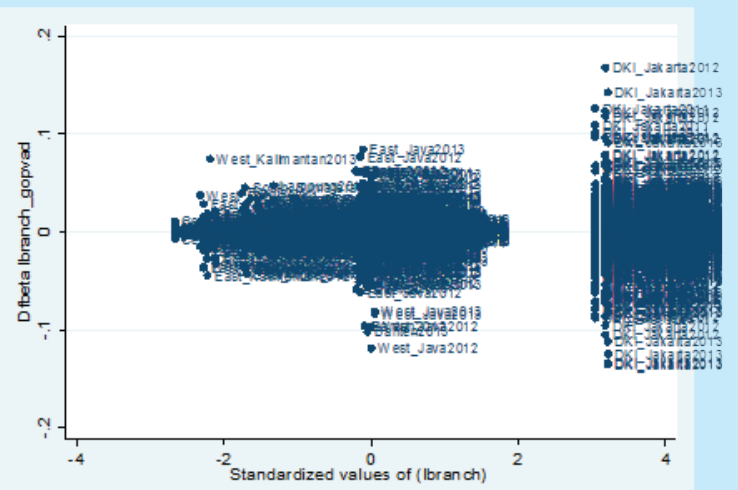

Appendix 7.

Scatter Plot of DF-BETA log(branch) and Standardize values of log(branch) 

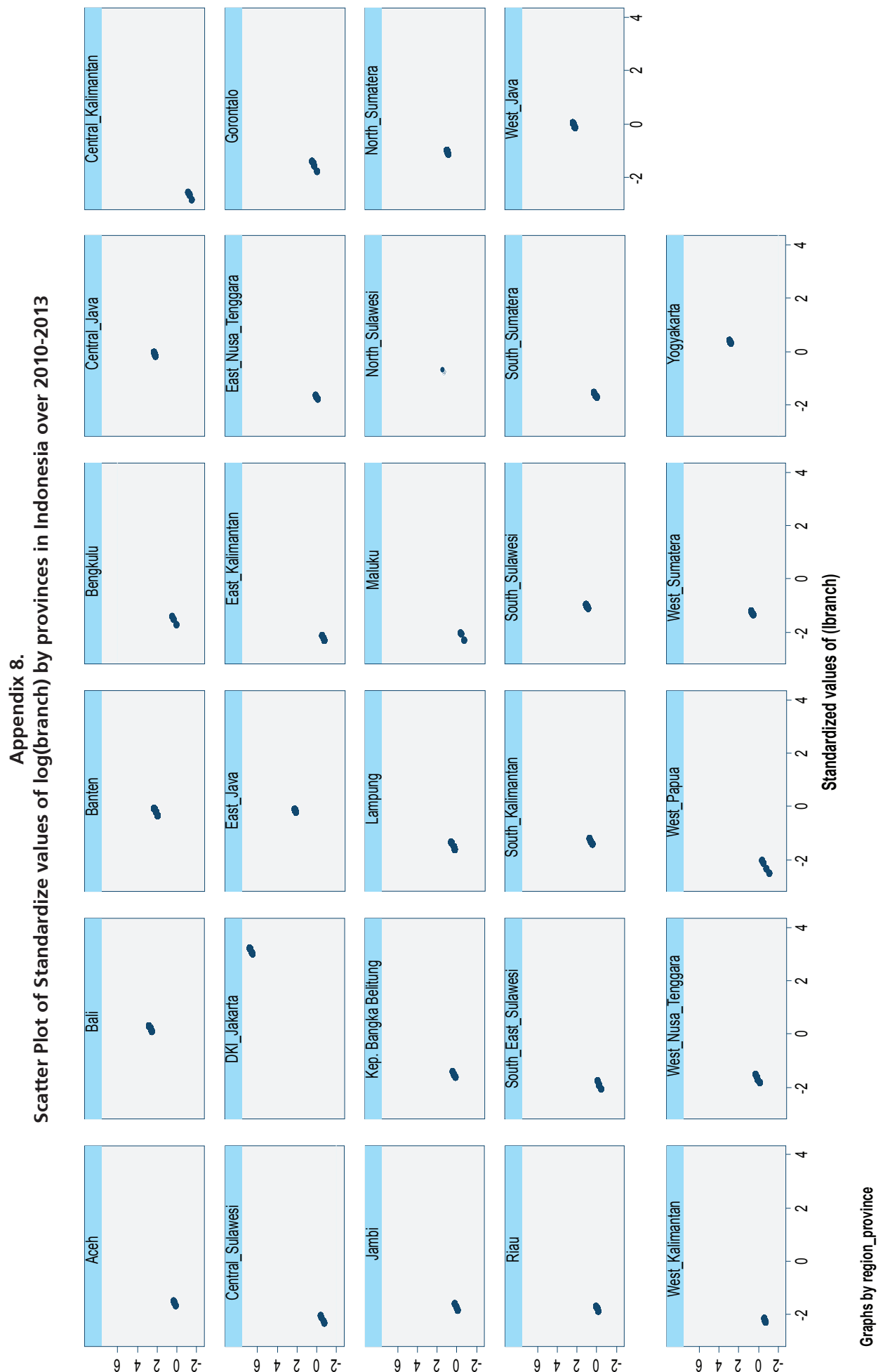
318 Buletin Ekonomi Moneter dan Perbankan, Volume 19, Nomor 3, Januari 2017

\begin{tabular}{|c|c|c|c|}
\hline \multicolumn{4}{|c|}{ Appendix 9. Variance Inflation Factor (VIF) } \\
\hline \multirow{2}{*}{ Variable } & \multicolumn{3}{|c|}{ Variance Inflation Factors (VIF) } \\
\hline & (1) & (2) & (3) \\
\hline Ihousehold & 43.17 & & \\
\hline Ibranch1 & 42.98 & 2.08 & 1.33 \\
\hline unemployment & 3.68 & 1.91 & 1.90 \\
\hline Idist & 3.44 & 3.15 & \\
\hline inflation1 & 3.08 & 3.07 & 2.90 \\
\hline pov_rate & 2.64 & 2.64 & 2.08 \\
\hline Irwage & 2.56 & 2.54 & 2.40 \\
\hline gop_vad & 1.00 & 1.00 & 1.00 \\
\hline Mean VIF & 12.82 & 2.34 & 1.94 \\
\hline
\end{tabular}

